\title{
Interference by Branched-Chain Amino Acids in the Assay of Alanine with Alanine Dehydrogenase
}

\author{
By PATRICIA LUND and GABRIEL BAVEREL* \\ Metabolic Research Laboratory, Nuffield Department of Clinical Medicine, \\ Radcliffe Infirmary, Oxford OX2 6HE, U.K.
}

(Received 9 June 1978)

\begin{abstract}
Commercial preparations of alanine dehydrogenase from Bacillus subtilis are contaminated to varying extents with activity towards branched-chain amino acids. The $K_{\mathrm{m}}$ values for these amino acids are of the same order as for L-alanine (about $10^{-3} \mathrm{M}$ ). The branched-chain amino acid dehydrogenase activity is lost on dialysis for 2-4h against water or 2 mM-EDTA.
\end{abstract}

In experiments on the effect of leucine on hepatic amino acid metabolism we found an apparent accumulation of alanine. The 'alanine' was the result of a direct reaction of leucine with the alanine dehydrogenase (EC 1.4.1.1) of Bacillus subtilis under the assay conditions. Williamson (1974) was careful to point out that the enzyme preparation is not absolutely specific for alanine, as Yoshida \& Freese (1965) had reported that isoleucine and valine also react, although the $K_{m}$ of these substrates (about $2 \times 10^{-1} \mathrm{M}$ ) appeared to eliminate them as sources of error in the alanine assay. Moreover Yoshida \& Freese (1965) found no reaction with leucine. In view of this report the reaction of the alanine dehydrogenase preparation with a low concentration of leucine was unexpected. To clarify the apparent discrepancy some of the properties of the enzyme have been re-examined. In contrast with Yoshida \& Freese (1965) we find that the branched-chain amino acids at relatively low concentration (less than $0.5 \mu \mathrm{mol}$ per cuvette) can react with the $B$. subtilis alanine dehydrogenase and cause a serious error in the assay of alanine.

The findings bear on the question (see Ruderman, 1975; Felig, 1976) to what extent the branchedchain amino acids can provide the carbon skeleton of the large amounts of alanine release by skeletal muscle (London et al., 1965; Pozefsky et al., 1969). In some of this work alanine was measured by the enzymic method in the presence of high concentrations of an added branched-chain amino acid (see e.g., Ruderman \& Lund, 1972; Ruderman \& Berger, 1974; Goldstein \& Newsholme, 1976; Snell \& Duff, 1977). In all cases the enzyme was obtained from the same commercial source. It is possible that the added amino acid may have contributed directly to the 'alanine' formation. Odessey

* Present address: Laboratoire de Physiologie, U.E.R. Alexis-Carrell, Rue Guillaume Paradin, 69008 Lyon, France. et al. (1974) made this point in discussing published work on the origin of the alanine released by skeletal muscle. Their critical comments are supported by the quantitative evidence given in the present paper.

\section{Experimental}

\section{Materials}

L-Alanine dehydrogenase from $B$. subtilis (150 units $/ \mathrm{ml}$ ) was obtained from Boehringer Corporation (London), Lewes, East Sussex, U.K. L-Leucine was a product of Koch-Light Laboratories, Colnbrook, Bucks., U.K., and L-isoleucine, Lalanine, L-serine and $\mathrm{L}$-valine were from $\mathrm{BDH}$ Chemicals, Poole, Dorset, U.K. Other amino acids were either from BDH or from Sigma (London) Chemical Co., Poole, Dorset, U.K. Keto acid analogues of branched-chain amino acids were a gift from Dr. MacKenzie Walser.

$\mathrm{L}-\left[1 .{ }^{14} \mathrm{C}\right]$ Leucine was obtained from The Radiochemical Centre, Amersham, Bucks., U.K., and converted into 4-methyl-2-oxo[1-14 $\mathrm{C}]$ pentanoate (oxoleucine) by Dr. P. Ferré, using L-amino acid oxidase and catalase. The keto acid was separated by chromatography from the remaining $\left[1-{ }^{14} \mathrm{C}\right]$ leucine. For details, see Lund (1978).

\section{Methods}

The alanine assay was carried out at room temperature $\left(20^{\circ} \mathrm{C}\right)$ as described by Williamson (1974) with the modifications given in the text. Some relevant kinetic properties of the alanine dehydrogenase preparation were measured at $25^{\circ} \mathrm{C}$ by using a Gilford 222 recording photometer with automatic sample changer. For the oxidative deamination reaction the cuvettes contained: $1 \mathrm{ml}$ of $0.1 \mathrm{M}$-sodium 
carbonate buffer, $\mathrm{pH} 10.0$, containing 2mM-EDTA, $0.1 \mathrm{ml}$ of $2 \% \mathrm{NAD}^{+}$, amino acid substrate and water to $2.0 \mathrm{ml}$. The reaction was started with $0.01 \mathrm{ml}$ of diluted enzyme which had been dialysed for a short time to remove ammonium ions. For the reductive amination the cuvettes contained: $1 \mathrm{ml}$ of $0.1 \mathrm{M}$-Tris/ $\mathrm{HCl}$ buffer, $\mathrm{pH} 8.5$, containing $2 \mathrm{mM}$ EDTA, $0.2 \mathrm{ml}$ of $1 \mathrm{M}-\mathrm{NH}_{4} \mathrm{Cl}, 0.06 \mathrm{ml}$ of $0.5 \%$ NADH with keto acid substrate, water and diluted enzyme to $2.0 \mathrm{ml}$.

The quantitative reductive amination of low concentrations of oxoleucine was confirmed by separation on an Amberlite IR $120\left(\mathrm{H}^{+}\right.$form) column (approx. $1 \mathrm{~cm} \times 5 \mathrm{~cm}$ ), which adsorbs leucine, but not the keto acid. Cuvettes were set up to contain about $0.2 \mu \mathrm{mol}$ of oxo[ $\left[1{ }^{14} \mathrm{C}\right]$ leucine in the assay system at pH 8.5. The reaction was followed to completion at $340 \mathrm{~nm}$. A sample $(2 \mathrm{ml}$, containing 41000 c.p.m.) was added to the column and eluted with water. Only $1.5 \%$ of the radioactivity appeared in the eluate so that conversion of oxoleucine into leucine was virtually quantitative.

\section{Results and Discussion}

\section{Reaction of commercial alanine dehydrogenase from} B. subtilis with branched-chain amino acids

The non-specificity of batch no. $1197112 / 1$ is illustrated in Table 1 . At the enzyme concentration routinely used in this laboratory $(0.75 \mathrm{unit} / \mathrm{ml}$ in the cuvette) the assay of $0.1 \mu \mathrm{mol}$ of alanine was essentially complete after $30 \mathrm{~min}$, but the abrupt end-point was masked in the presence of $0.1 \mu \mathrm{mol}$ of leucine. At $60 \mathrm{~min}$ over $30 \%$ of the leucine had reacted, irrespective of the presence of alanine. On increasing the leucine to $0.5 \mu \mathrm{mol}$ in the cuvette the 'alanine' found was overestimated by $70 \%$ at $30 \mathrm{~min}$, and by over $100 \%$ at $60 \mathrm{~min}$. Of the branchedchain amino acids, valine reacted least quickly, but still gave an overestimate of alanine of $30 \%$ at $30 \mathrm{~min}$ and $61 \%$ at $60 \mathrm{~min}$ under the same conditions. Serine also reacted to a very minor extent under these conditions, showing only as a slight creep after deamination of alanine was complete (Table 1). There was no reaction when any of the following protein amino acids were tested individually at $0.25 \mathrm{~mm}$ final concentration in the cuvette: arginine, asparagine, aspartate, cysteine, glutamate, glutamine, glycine, histidine, lysine, methionine, phenylalanine, proline, serine, threonine, tryptophan, tyrosine. It should be noted that the enzyme concentration used $(0.75 \mathrm{unit} / \mathrm{ml})$ is almost 20 -fold that recommended by Williamson (1974). When the amount of enzyme was decreased to 75 munits $/ \mathrm{ml}$ the assay of $0.1 \mu \mathrm{mol}$ of alanine took $2 \mathrm{~h}$ to reach completion and interference by $0.1 \mu$ mol of leucine was only $10 \%$. When the amount of leucine, isoleucine or valine was $0.5 \mu \mathrm{mol}$ per cuvette the interference became more than $30 \%$ at $2 \mathrm{~h}$. These amino acids reacted to the same extent whether the assay was carried out at $\mathrm{pH} 10.0$, as in the published method (Williamson, 1974), or at pH9.0 when the correction for the reagent blank is smaller and when glutamate and alanine can be determined successively in the same cuvette.

There is a major difference between the commercial enzyme preparation used by us, a suspension in $2.4 \mathrm{M}-\left(\mathrm{NH}_{4}\right)_{2} \mathrm{SO}_{4}$, and that prepared by Williamson et al. (1967) (see also Williamson, 1974) in that the latter was dialysed to remove $\left(\mathrm{NH}_{4}\right)_{2} \mathrm{SO}_{4}$. To test whether the higher enzyme requirement, with the accompanying interference by branched-chain amino acids, was the result of product inhibition by ammonium ions $(24 \mathrm{~mm}$ in the cuvette on addition of $10 \mu$ l of enzyme) the enzyme was dialysed.

Table 1. Reaction of branched-chain amino acids in the alanine assay: effect of concentration of alanine dehydrogenase For experimental details, see the text. Alanine dehydrogenase [batch no. 1197112/1 from Boehringer Corporation (London)] was used in the assays. An enzyme concentration of 0.75 unit $/ \mathrm{ml}$ in the cuvette is given by $0.01 \mathrm{ml}$ of the undiluted enzyme. The volume in each cuvette was $2.01 \mathrm{ml}$.

\section{Amino acid added $(\mu \mathrm{mol})$}

Ala (0.1)

Ala (0.1)+Leu (0.1)

Ala (0.1)+Leu (0.5)

Ala (0.1)+ Ile (0.5)

Ala (0.1) + Val (0.5)

Ala (0.1)+Ser (0.5)

Ala (0.1)

Leu (0.1)

Leu (0.5)

Ile (0.5)

Val (0.5)
Enzyme concentration (units/ml)

0.75

0.75

0.75

0.75

0.75

0.75

75

75

75

75

75

\begin{tabular}{ccccc}
\multicolumn{5}{c}{ 'Alanine' found $(\mu \mathrm{mol})$} \\
\hline At 30min & At 45min & At 60min & At 75min & At 120min \\
0.097 & 0.100 & 0.100 & 0.100 & \\
0.120 & 0.126 & 0.132 & 0.138 & \\
0.166 & 0.185 & 0.202 & 0.215 & \\
0.147 & 0.162 & 0.176 & 0.185 & \\
0.135 & 0.148 & 0.161 & 0.169 & \\
0.097 & 0.102 & 0.104 & 0.107 & \\
0.060 & 0.074 & 0.082 & 0.089 & 0.098 \\
0.002 & 0.003 & 0.004 & 0.006 & 0.010 \\
0.011 & 0.015 & 0.020 & 0.024 & 0.035 \\
0.009 & 0.014 & 0.018 & 0.022 & 0.034 \\
0.007 & 0.010 & 0.015 & 0.018 & 0.029
\end{tabular}




\section{Effect of dialysis}

Dialysis of the enzyme at $4^{\circ} \mathrm{C}$ in the presence of bovine serum albumin [ $0.1 \mathrm{ml}$ of enzyme suspension $+0.4 \mathrm{ml}$ of $10 \%(\mathrm{w} / \mathrm{v})$ albumin] speeded up the alanine assay without decreasing the interference by leucine. Short-term dialysis $(1 \mathrm{~h})$ against water or for 2-4h against $10 \mathrm{~mm}$-Tris/HCl buffer, $\mathrm{pH} 7.4$, or $10 \mathrm{~mm}$ 2-mercaptoethanol in $10 \mathrm{~mm}$-sodium phosphate buffer, pH7.0, led to a small loss of activity with all amino acids. However, dialysis against water or 2mM-EDTA for 2-4h resulted in complete loss of activity towards branched-chain amino acids. There was no re-activation by cysteine $(1 \mathrm{mM})$, dithiothreitol $(1 \mathrm{~mm})$ or by neutral supernatants of liver extracts after deproteinization by $\mathrm{HClO}_{4}$ or by boiling.

\section{$K_{m}$ of the enzyme preparation for amino acids}

The $K_{\mathrm{m}}$ of the enzyme (dialysed for a short time against $10 \mathrm{~mm}$-Tris/ $\mathrm{HCl}$, pH 7.4, to remove ammonium ions) for L-alanine $\left(2.6 \times 10^{-3} \mathrm{M}\right)$, L-serine $\left(2.5 \times 10^{-2} \mathrm{M}\right)$ or for pyruvate $\left(5.3 \times 10^{-4} \mathrm{M}\right)$ were found to be of the same order as reported by Yoshida \& Freese (1965) for their enzyme preparation from B. subtilis $\left(1.73 \times 10^{-3} \mathrm{M}, 5.7 \times 10^{-2} \mathrm{M}\right.$ and $5.4 \times 10^{-3} \mathrm{M}$ respectively). The low affinity of the serine dehydrogenase for serine means that it can be ignored as a possible source of error in the assay of alanine except when a high concentration of added serine is present. In the same dialysed enzyme preparation the $K_{\mathrm{m}}$ values for $\mathrm{L}$-leucine and $\mathrm{L}$-isoleucine were about $6 \times 10^{-3} \mathrm{M}$ and $1 \times 10^{-3} \mathrm{M}$ respectively, the latter more than 100 -fold lower than reported by Yoshida \& Freese (1965) for isoleucine. They found no reaction of their enzyme preparation with leucine. The $V_{\max }$. with leucine or isoleucine, relative to alanine, in the present preparation was about $3 \%$.

\section{Branched-chain amino acid dehydrogenase and alanine dehydrogenase are different proteins}

The following findings indicate that the two reactions are catalysed by separate proteins: (i) dehydrogenase activity with branched-chain amino acids, but not with alanine, is lost on dialysis, (ii) the reductive amination reaction at low pyruvate concentration is not inhibited by high concentrations of leucine, (iii) the ratio of the activities of alanine dehydrogenase and branched-chain amino acid dehydrogenase is not constant. Batch no. 1367313/1 contained less than $10 \%$ of the activity towards leucine (but a slightly higher activity towards serine) than the preparation on which the data presented in this paper were obtained.

\section{Use of alanine dehydrogenase preparations for the assay of branched-chain keto acids}

The low $V_{\max }$. rules out even heavily contaminated batches of the commercial enzyme for use in the determination of concentrations of branched-chain amino acids. However, the reverse reaction could provide a convenient means of determining concentrations of branched-chain keto acids. The quantitative reductive amination of low concentrations (0.025-0.2 $\mu \mathrm{mol}$ per cuvette) of 4-methyl-2-oxopentanoate (oxoleucine) occurred within $60 \mathrm{~min}$ at pH 8.5 (see under 'Methods'). So far the assay has not been tested in tissue extracts, in which total branched-chain keto acid concentrations are expected to be extremely low (see Krebs \& Lund, 1977). A more likely application would be for the determination of the keto acids when the parent amino acid or keto acid is added experimentally as substrate, or in conditions (for example maple-syrup-urine disease) in which the keto acids accumulate. A separate assay using lactate dehydrogenase could be carried out to correct for the pyruvate or hydroxypyruvate (Meister, 1952) content of the sample.

\section{Comment}

The purpose of this paper is to point out that the dehydrogenase active towards branched-chain amino acids which is found in commercial alanine dehydrogenase must be taken into account when the assay of alanine is carried out in the presence of leucine, isoleucine or valine. The broader specificity and higher affinity towards these three amino acids make the commercial preparation different from the enzyme from $B$. subtilis described by Yoshida \& Freese (1965) on which the alanine assay was based. In respect to specificity to other amino acids it appears to be very similar to that of Yoshida \& Freese (1965). If a specific branched-chain amino acid dehydrogenase could be isolated at high activity it would provide a convenient assay for the three branched-chain amino acids for which there is so far no enzymic assay available. This remains to be explored. As discussed above, the enzymic assay of branched-chain keto acids is already feasible.

In the meantime, interference by branched-chain amino acids in the assay of alanine can be eliminated very simply by dialysis of the commercial alanine dehydrogenase against water.

P. L. is a member of the External Staff of the Medical Research Council.

\section{References}

Felig, P. (1976) in The Year in Metabolism 1975-1976 (Freinkel, N., ed.), pp. 113-136, Plenum Medical Book Co., New York and London

Goldstein, L. \& Newsholme, E. A. (1976) Biochem. J. 154, 555-558

Krebs, H. A. \& Lund, P. (1977) Adv. Enzyme Regul. 15, 375-394

Vol. 174 
London, D. R., Foley, T. H. \& Webb, C. G. (1965) Nature (London) 208, 588-589

Lund, P. (1978) in Biochemical and Clinical Aspects of Ketone Body Metabolism (Söling, H.-D. \& Seufert, C.-D., eds.), G. Thieme Verlag, Leipzig, in the press

Meister, A. (1952) J. Biol. Chem. 197, 309-317

Odessey, R., Khairallah, E. A. \& Goldberg, A. L. (1974) J. Biol. Chem. 249, 7623-7629

Pozefsky, T., Felig, P., Tobin, J. D., Soeldner, J. S. \& Cahill, G. F. (1969) J. Clin. Invest. 48, 2273-2282

Ruderman, N. B. (1975) Annu. Rev. Med. 26, 245258
Ruderman, N. B. \& Berger, M. (1974) J. Biol. Chem. 249, 5500-5506

Ruderman, N. B. \& Lund, P. (1972) Isr. J. Med. Sci. 8, 295-302

Snell, K. \& Duff, D. A. (1977) Biochem. J. 162, 399-403

Williamson, D. H. (1974) in Methods of Enzymatic Analysis (Bergmeyer, H. U., ed.), vol. 4, pp. 1679-1682, Academic Press, London and New York

Williamson, D. H., Lopes-Vieira, O. \& Walker, B. (1967) Biochem. J. 104, 497-502

Yoshida, A. \& Freese, E. (1965) Biochim. Biophys. Acta 96, 248-262 